\section{Д.Ю. Плотников}

Э. Рат об «имперском контексте» Крымской войны 1853-1856 гг. Рецензия на: Rath A.C. The Crimean War in Imperial Context, 1854-1856. New York: Palgrave Macmillan, 2015. xvii, 301 p.

DOI: $10.31518 / 2618-9100-2018-2-12$

УДК 94(47).073.5

Выходные данные для цитирования:

Плотников Д.Ю. Э. Рат об «имперском контексте» Крымской войны 1853-1856 гг. Рецензия на: Rath A.C. The Crimean War in Imperial Context, 1854-1856. New York: Palgrave Macmillan, 2015. xvii, 301 p. // Исторический курьер. 2018. № 2. Статья 12. URL:

http://istkurier.ru/data/2018/ISTKURIER-2018-2-12.pdf
Dmitriy Plotnikov*

\section{A. Rath on the «Imperial Context» of the Crimean War of 1853-1856. Review of: Rath A.C. The Crimean War in Imperial Context, 1854-1856. New York: Palgrave Macmillan, 2015. xvii, 301 p.}

DOI: $10.31518 / 2618-9100-2018-2-12$

How to cite:

Plotnikov Dmitriy Yu. A. Rath on the «imperial context» of the Crimean War of 1853-1856. Review of: Rath A.C. The Crimean War in Imperial Context, 1854-1856. New York: Palgrave Macmillan, 2015. xvii, 301 p. // Historical courier, 2018, \# 2. Article 12. [Available online:]

http://istkurier.ru/data/2018/ISTKURIER-2018-2-12.pdf

Abstract: The review covers A. Rath's "The Crimean War in Imperial Context" published in 2015. An excellent source base including materials in different languages and an insightful analysis of the economic warfare on secondary naval theaters are among the book's strengths. However, the author's analysis of Russian annexation of the Amur river valley is unconvincing, and the strategic importance of potential bombardment of St. Petersburg is greatly exaggerated. That being said, the monograph is still a valuable addition to the historiography of the Crimean War.

Keywords: Crimean War; Russian empire; historiography; military history.

The article has been received by the editor on 07.09.2018.

Full text of the article in Russian and references in English are available below.

Аннотация: Рецензия посвящена монографии Э. Рата «Крымская война в имперском контексте», опубликованной в 2015 году. К достоинствам книги следует отнести великолепную источниковую базу и проницательный анализ торговой войны на второстепенных морских театрах. В то же время, авторский анализ русской аннексии Приамурья неубедителен, а стратегическая значимость потенциальной бомбардировки Санкт-Петербурга существенно переоценена. Тем не менее, работа являет собой ценное дополнение к историографии Крымской войны.

Ключевые слова: Крымская война; Российская империя; историография; военная история.

Терминологическая инерция зачастую играет с историками злую шутку: устоявшееся в историографии наименование, сколь угодно отличное от сути описываемого явления, может легко зажить собственной жизнью и начать самостоятельно определять восприятие тех или иных исторических событий. В полной мере это применимо и к Крымской войне 1853-1856 гг., название которой отсылает лишь к военным действиям на территории Крымского

\footnotetext{
* Плотников Дмитрий Юрьевич, стажёр-исследователь Института истории Сибирского отделения Российской академии наук (г. Новосибирск, Россия), e-mail: d.plotnikov@alumni.nsu.ru

Plotnikov Dmitriy Yurievich, junior researcher, Institute of History of the Siberian Branch of the Russian Academy of sciences (Novosibirsk, Russia), e-mail: d.plotnikov@alumni.nsu.ru
} 
полуострова - являвшимся, между тем, центральной, но далеко не единственной частью масштабного конфликта. В результате подавляющее большинство работ по истории войны сосредотачиваются на Чёрном море и Крымском ТВД, а военные действия на Дунае и Кавказе, равно как и морские кампании на Балтийском и Белом морях и Тихом океане, удостаиваются внимания по остаточному принципу. Историки неоднократно восставали против этой «терминологической диктатуры» - так, Л.Г. Бескровный выдвинул логически безупречное, но неудобоваримое наименование «война России с европейской коалицией» ${ }^{1}$, а Э. Ламберт упорно, но безуспешно боролся с редакторами, стремясь озаглавить свою монографию «The Russian War», в соответствии с первоначальной англоязычной традицией ${ }^{2}$. Учитывая, однако, что «Крымская война» и поныне прочно удерживает свои позиции, борьбу с ветряной мельницей терминологической инерции следует признать заведомо проигрышной. Тем любопытнее выглядит иной подход: создание работ, специально посвящённых истории войны за пределами Крымского полуострова и Чёрного моря, стремящихся заполнить лакуны в традиционных нарративах, пусть даже и под некорректным «Крымским» ярлыком. Примером именно такой тенденции является монография Э. Рата «Крымская война в имперском контексте».

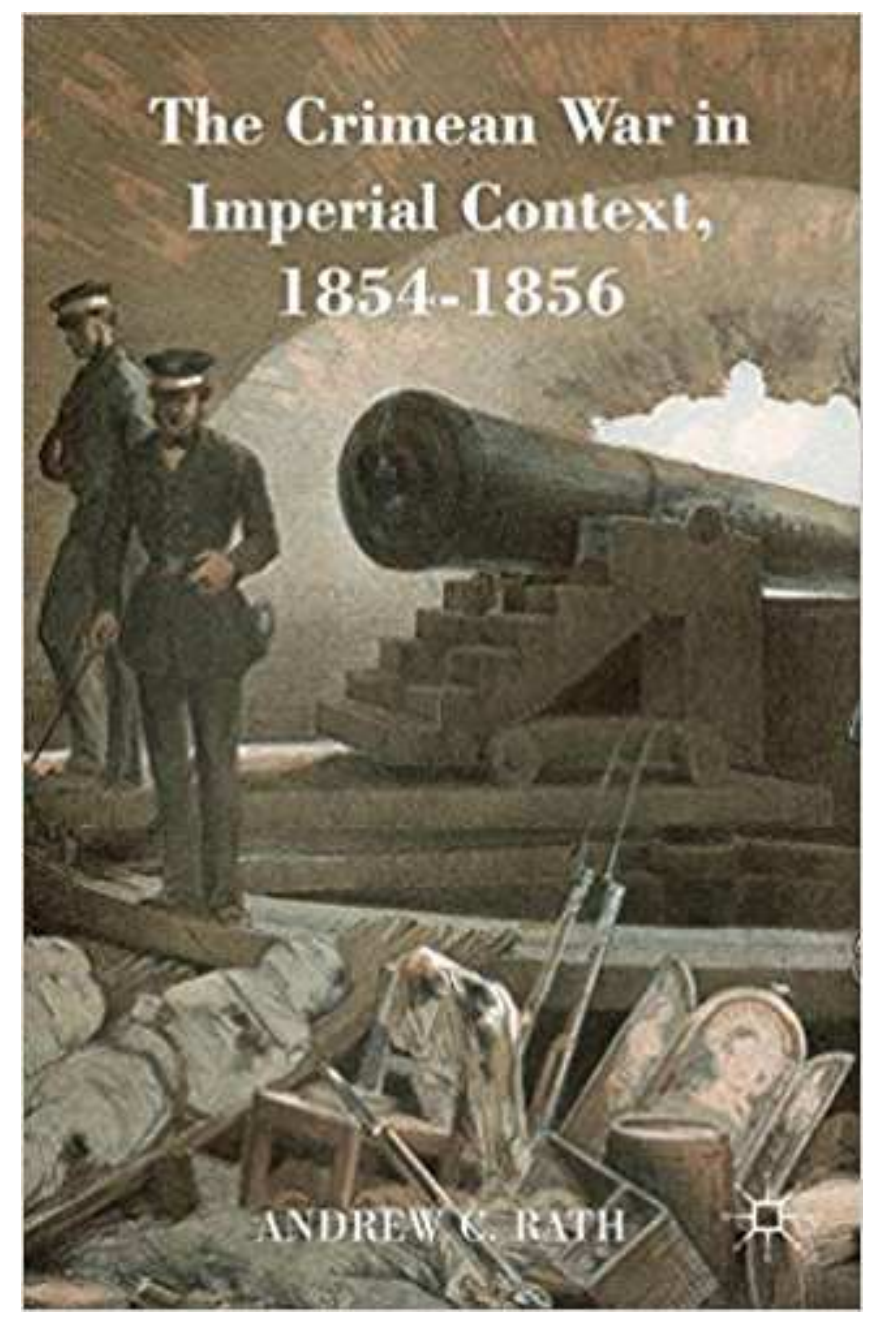

Источниковая база исследования заслуживает самой высокой оценки: автор привлёк к работе материалы из многочисленных английских, французских, русских и американских архивов. Помимо англо-, франко- и русскоязычных источников, для раскрытия отдельных тем использовались материалы на немецком, шведском, финском, китайском и японском

\footnotetext{
${ }^{1}$ Бескровный Л.Г. Русское военное искусство ХІХ в. М., 1974. С. 212.

${ }^{2}$ Lambert A.D. The Crimean War British Grand Strategy against Russia, 1853-56. Farnham, 2011. P. 7.
} 
языках. Более того, историк открыто осуждает своих коллег, готовых удовлетвориться в исследовании лишь англоязычными источниками, подчёркивая весь вред такого самоограничения ${ }^{1}$. И такую позицию, и сам факт привлечения столь лингвистически широкой базы, можно только приветствовать. Поставленная же автором цель соответствует серьёзности подведённого под неё фундамента: историк стремится не только составить подробное описание военных действий на второстепенных морских театрах, но и вписать его в политический контекст противостояния России и Великобритании как двух империй.

Один из центральных сюжетов, исследуемых в монографии, - борьба на экономическом фронте и, в частности, торговая война. Центральную роль в авторском анализе играет практика «изъятий», ограждавшая те или иные формы экономической деятельности противника от вооружённого насилия и гарантировавшая безопасность судам и товарам, которые иначе стали бы законной добычей союзных эскадр. Так, англо-французские силы на Белом море, посвятившие себя полному уничтожению коммерческого мореплавания в районе, сделали примечательное исключение для русской торговли со шведской провинцией Финнмарк, явственно вызванное стремлением расположить к себе Швецию как потенциального союзника ${ }^{2}$. Схожее развитие событий наблюдалось и в Северной Америке, где подданные воюющих сторон в лице Российско-Американской компании и Компании Гудзонова залива продолжали торговать друг с другом напрямую, не спеша отказываться от собственных прибылей ради скромного экономического урона враждебной державе 3 . Разбор этих сюжетов представляет немалый интерес для истории экономической борьбы в годы войны, но мог бы только выиграть от расширения географических рамок работы. Точь-вточь такие же явления наблюдались и на Чёрном море, где нейтральные европейские суда продолжали экспортировать российское сырьё в Великобританию даже в разгар войны ${ }^{4}$, и на Кавказе, где победоносные русские войска сквозь пальцы смотрели на английскую и французскую торговлю с Персией и собственно русским Закавказьем 5 . Таким образом, автору удаётся затронуть крайне важную и любопытную тему экономического противостояния в Крымскую войну и убедительно развить несколько связанных с ней сюжетов - но не раскрыть её в той мере, в какой она этого заслуживает.

Немалое внимание автор уделяет и Дальнему Востоку, однако в этом случае его построения выглядят менее убедительно. Определённый интерес представляет освещение русских и английских дипломатических миссий в Японию в годы войны ${ }^{6}$. Однако осторожную попытку автора связать присоединение Приамурья с ростом антианглийских настроений при дворе Николая I и соответственным ослаблением «партии Нессельроде», остерегавшейся аннексий в Китае, чтобы не спровоцировать конфликт с Великобританией ${ }^{7}$, следует считать натяжкой: русское продвижение в долину Амура началось задолго до войны и даже спора о Святых местах и завершилось бы аннексией даже без Крымской войны.

Собственно военную составляющую монографии также стоит воспринимать с существенной долей скептицизма. Разбор военно-морских кампаний на Балтике в 1854-1855 гг., равно как и англо-французской подготовки к кампании 1856 г., венчается выводом о том, что угроза бомбардировки Кронштадта и Санкт-Петербурга была одним из факторов, обусловивших миролюбие Александра $\mathrm{II}^{8}$. Эта идея, очевидно, позаимствована у

\footnotetext{
${ }^{1}$ Rath A.C. The Crimean War in Imperial Context, 1854-1856. New York, 2015. P. xiii.

2 Ibid., pp. 15-16, 77, 85-86.

${ }^{3}$ Ibid., p. 117.

${ }^{4}$ Anderson O. Economic Warfare in the Crimean War // The Economic History Review. New Series, V. 14. 1961, №. 1 . P. 40.

5 Плотников Д.Ю. Война и коммерция в Восточной Анатолии: причины русской политики в отношении британской торговли в 1854-1855 гг. // Актуальные проблемы исторических исследований: взгляд молодых учёных: Сборник материалов четвёртой Всероссийской молодёжной научной конференции. Новосибирск: Параллель; Институт истории СО РАН, 2015. С. 60-68.

${ }^{6}$ Rath A.C. Op. cit. PP. 131-150.

${ }^{7}$ Ibid., pp. 112-113.

${ }^{8}$ Ibid., pp. xiv, xvii, 200.
} 
британского историка Э. Ламберта ${ }^{1}$ - едва ли случайно то, что труды последнего занимают в библиографическом списке больше места, чем работы любого другого автора. Однако монография Э. Рата демонстрирует в этом отношении тот же недостаток, что и труд его британского вдохновителя: если подготовка союзных флотов к балтийской кампании 1856 г. проанализирована добросовестно и убедительно, то постулируемая связь между потенциальной бомбардировкой Петербурга и русской готовностью заключить мир повисает в воздухе. Примечательно, что автор признаёт: создать реальную угрозу базе российского Балтийского флота и столице империи можно было лишь при участии сильного десанта ${ }^{2}$, бомбардировка же силами одного флота не могла рассчитывать на сколько-нибудь значительный стратегический результат и неизбежно сводилась к политическому жесту. Более того, сам автор соглашается с М.П. Погодиным в оценке бомбардировки Соловецкого монастыря в 1854 г. как бессмысленной акции, не приносившей никакого военного результата и лишь разжигавшей в русских ненависть к противнику ${ }^{3}$. Определить, почему демонстративная бомбардировка столицы империи, в равной степени лишённая шансов подорвать военную мощь страны, должна была оказать какое-то иное воздействие на настроения Александра II и его подданных, автор предоставляет читателю.

Эти недостатки, впрочем, не отменяют положительных сторон труда. «Крымская война в имперском контексте» заслуживала бы благосклонного внимания уже в силу трудолюбия автора и его ответственного подхода к подбору источников, а весьма любопытные наблюдения, касающиеся экономического противостояния сторон, окончательно отметают сомнения в том, что перед читателем находится ценное дополнение к историографии войны. Главная же слабость труда заключается даже не в ошибках интерпретации, а в исходной посылке книги и вырастающих из неё географических рамках. Встав в принципиальную оппозицию «крымоцентричности» существующей историографии, автор уходит в другую крайность - и в результате последовательного игнорирования Крыма, Дуная, Кавказа и Чёрного моря оказывается не в состоянии полноценно отразить тот самый «имперский контекст», военный и экономический, что вынесен в заглавие его работы.

\section{Статья поступила в редакциию 07.09.2018 г.}

\section{Лumepamypa}

Бескровный Л.Г. Русское военное искусство XIX в. М.: «Наука», 1974. 361 с.

Плотников Д.Ю. Война и коммерция в Восточной Анатолии: причины русской политики в отношении британской торговли в 1854-1855 гг. // Актуальные проблемы исторических исследований: взгляд молодых учёных. Сборник материалов четвёртой Всероссийской молодёжной научной конференции. Новосибирск: Параллель; Институт истории СО РАН, 2015. C. 60-68.

Anderson O. Economic Warfare in the Crimean War // The Economic History Review. New Series. 1961. V. 14. №1. Pp. 34-47.

Lambert A.D. The Crimean War British Grand Strategy against Russia, 1853-56, $2^{\text {nd }}$ edition. Farnham: Rouledge, 2011. xvii, 369 p.

Rath A.C. The Crimean War in Imperial Context, 1854-1856. New York: Palgrave Macmillan, 2015. xxiv, $301 \mathrm{p}$.

\section{References}

Beskrovniy L.G. Russkoye voyennoye iskusstvo XIX v. [Russian Military Art of the $19^{\text {th }}$ century]. M.: Nauka, 1974.

\footnotetext{
${ }^{1}$ Lambert A.D. Op. cit.

${ }^{2}$ Rath A.C. Op. cit. P. 57.

${ }^{3}$ Ibid., p. 94.
} 
Plotnikov D.Y. War and Commerce in the Eastern Anatolia: The Causes of Russian Policy toward the British Trade in 1854-1855 // Aktyalnye problem istoricheskirh issledovaniy: vzglyad molodykh ucheonykh. Sbornik materialov chetveortoy Vserossiyskoy molodeozhnoy nauchnoy konferentsii $=$ Current Problems of Historical Studies: The View of the Young Scientists. Proceedings of the Fourth All-Russian Youth Scientific Conference. Novosibirsk: Parallel, Institute of History SB RAS (2015): 60-68.

Anderson O. Economic Warfare in the Crimean War. The Economic History Review. New Series. Vol. 14, no. 1 (1961): 34-47.

Lambert A.D. The Crimean War British Grand Strategy against Russia, 1853-56, $2^{\text {nd }}$ edition. Farnham: Rouledge, 2011. xvii, 369 p.

Rath A.C. The Crimean War in Imperial Context, 1854-1856. New York: Palgrave Macmillan, 2015. xxiv, 301 p. 